ACTA UNIVERSITATIS LODZIENSIS

FOLIA LITTERARIA POLONICA 3(41) 2017

http://dx.doi.org/10.18778/1505-9057.41.09

Dorota Suska*

\title{
Dyskurs wokół śmierci Stanisława Pyjasa (językowe strategie zarządzania kryzysem w prasie krakowskiej)
}

\section{Wstęp}

7 maja 1977 roku w kamienicy przy ulicy Szewskiej w Krakowie znaleziono ciało Stanisława Pyjasa, współpracującego z KOR ${ }^{1}$ krakowskiego studenta filologii polskiej UJ. Tragiczna śmierć był katalizatorem wielu wydarzeń w Krakowie (z udziałem części środowiska studenckiego oraz opozycyjnego) niekorzystnych dla ówczesnej władzy (m.in. wezwanie do bojkotu Juwenaliów, marsze, protesty), które uderzały w jej zaplecze moralne, metody działania i ukazywały rosnącą siłę opozycji krakowskiej, współpracującej z ogólnopolską. Ogół tych zdarzeń spotkał się naturalnie z reakcją propagandową w środkach masowego przekazu; na początku jednak „sprawa Pyjasa” zaskoczyła decydentów siłą oddziaływania na nastroje społeczne i dopiero rozwój kryzysu politycznego, utrzymującego dynamikę do początków czerwca, uświadomił konieczność zorganizowania dyskursu prasowego, który zmierzał do jego zażegnania²

\footnotetext{
* Dr hab. prof. AJD, e-mail: d_suska@op.pl; Akademia im. Jana Długosza w Częstochowie, Instytut Filologii Polskiej.

${ }^{1}$ Komitet Obrony Robotników powstał we wrześniu 1976 roku jako reakcja na represje robotników po strajkach z czerwca tego roku. Wiosną 1977 roku, na skutek intensyfikacji kontaktów pomiędzy warszawskim KOR-em a studenckimi środowiskami Krakowa, aparat bezpieczeństwa rozpoczął inwigilację tych środowisk, a następnie kontrofensywę wobec opozycji. Zob. Stanisław Pyjas - nieszczęśliwy wypadek czy morderstwo?, z komentarzem historyka, prof. Andrzeja Paczkowskiego; audycja z cyklu Dźwiękowy przewodnik po najnowszej historii Polski, PR, 15.04.1997, http://www.polskieradio.pl/39/156/Artykul/837672, Stanislaw-Pyjas-nieszczesliwy-wypadek-czy-morderstwo [dostęp: 16.04.2016].

${ }^{2}$ Sama peryfraza kryzysu: „sprawa Pyjasa” (pochodząca z ówczesnej prasy) jest przykładem języka ezopowego, typowego dla sytuacji uwikłań dramatycznych, gdy „trzeba powiedzieć, że stało się coś groźnego, wrogiego, niedobrego, nie informując, co stało się naprawdę". Michał Głowiński wymienia podobne formuły odnoszące się do manifestacji studentów krakowskich po śmierci Pyjasa: „to, co się stało (zdarzyło) w Krakowie” (M. Głowiński, Nowomowa po polsku, Wydawnictwo PEN, Warszawa 1991, s. 16).
} 


\section{Materiał badawczy i cel badań}

Podstawę materiałową prezentowanych analiz stanowią: teksty z prasy oficjalnej tytułów krakowskich (w tym przedruki) z okresu od 11 do 31 maja 1977 roku; ponadto oświadczenia studentów funkcjonujące wówczas w obiegu nieoficjalnym i ulotka propagandowa z obiegu partyjnego. Wymienione materiały obejmuje edycja źródeł do historii opozycji: Opozycja małopolska $w$ dokumentach $1976-1980^{3}$

Poddane analizie teksty ukazują język propagandy politycznej drugiej połowy lat $70 .{ }^{4}$ Zakładam, że język propagandy obejmuje taki podtyp, który można nazwać komunikacją kryzysową: aktywizowany doraźnie, gdy mają miejsce wydarzenia przełomowe z punktu widzenia interesu aparatu partyjnego i państwowego ${ }^{5}$. Język staje się wówczas podstawowym narzędziem zarządzania kryzysem, a w komunikacyjną intencję sterowania odbiorcą (właściwą w ogólności propagandzie) wpisane są intencje szczegółowe, zdeterminowane aktualnymi zdarzeniami i koniecznością ich ukazania z punktu widzenia nadawcy (w sposób przez niego założony, z narzuconą interpretacją, wartościowaniem) ${ }^{6}$. Z racji stosunku do rzeczywistości, intencji, celu strategia ta bazuje na manipulacji, tak bowiem postrzega się

zabiegi, za pomocą których człowiek usiłuje kształtować postawy i zachowania innych ludzi, które uważamy za nieuczciwe. Nieuczciwość użytych środków polega bądź na wyraźnym kłamstwie, bądź na zatajeniu tego, co odbiorca powinien wiedzieć, m.in. na nieujawnianiu rzeczywistych celów, którym służą ukryte środki ${ }^{7}$.

Celem analizy jest próba wskazania specyficznych właściwości pragmatycznych tekstów prasowych (i innych realizacji tekstowych) oraz reprezentatywnych wykładników językowych w powiązaniu z kolejnymi składnikami zdarzenia komunikacyjnego, organizującego dyskurs prasowy wokół „sprawy Pyjasa”.

${ }^{3}$ Opozycja małopolska $w$ dokumentach 1976-1980, wybór i oprac. A. Roliński, Fundacja Centrum Dokumentacji Czynu Niepodległościowego, Kraków 2003. Przy lokalizacji omawianych tekstów podaję w nawiasie skrót: OM.

${ }^{4}$ Rudymentarne cechy języka propagandy (nowomowy) podaje m.in. M. Głowiński, Nowomowa po polsku, s. 8-9.

${ }^{5}$ Nowomowa nie była odmianą monolityczną, niezmienną. Podatność na kontekst zewnętrzny pozwala mówić np. o propagandzie marcowej czy też o propagandzie stanu wojennego.

${ }^{6}$ Biorąc pod uwagę status ówczesnej prasy, nadawca tekstu - dziennikarz - reprezentował nadawcę politycznego.

${ }^{7}$ J. Puzynina, Słowo - wartość - kultura, TN KUL, Lublin 1997, s. 180.

${ }^{8}$ Ze względu na zakres tematyczny oraz role społeczne uczestników komunikacji jest to dyskurs polityczny (w obrębie szerszego dyskursu ideologicznego), na który nakłada się kryterium 


\section{1 maja: „Nieszczęśliwy wypadek"9}

Pierwsze wzmianki dotyczące śmierci Pyjasa prasa krakowska zamieściła po czterech dniach od zdarzenia - 11 maja, gdy w przestrzeni publicznej wciąż utrzymywało się przekonanie o niejasnych okolicznościach śmierci i udziale w niej służb bezpieczeństwa ${ }^{10}$. Wersja taka funkcjonowała w tekstach obiegu niezależnego: 9 maja oświadczenie wydał KOR, pisząc m.in. o „zbrodni” oraz konieczności wyjaśnienia i pociągnięcia do odpowiedzialności winnych, bez względu na zajmowane stanowisko ${ }^{11}$; w oświadczeniu Ruchu Obrony Praw Człowieka i Obywatela z 11 maja znalazły się słowa o "zamordowaniu” studenta, „męczeńskiej śmierci Stanisława Pyjasa”, żądanie wykrycia i ukarania „sprawców morderstwa"12. Reakcja prasy na rodzący się kryzys stała się zatem koniecznością, zwłaszcza wobec zaplanowanych na 13-15 maja Juwenaliów ${ }^{13}$. Teksty poświęcone śmierci studenta ukazały się w tej samej postaci w dwóch dziennikach - w nieeksponowanym miejscu gazety, w rubryce ujmującej zdarzenia losowe o niewielkiej randze, co wiązało się z manipulacyjnym umniejszaniem rangi podawanych informacji: „Dziennik Polski” (1977, nr 105, $11 \mathrm{~V}$, s. 6) zamieścił krótką notatkę na ostatniej stronie, w prawym dolnym rogu, w „Kronice wypadków”; podobnie „Gazeta Południowa” (1977, nr 105, 11 V, s. 8) - na końcowej stronie, z tytułem Nieszczęśliwy wypadek. Wobec złożonego kontekstu zdarzenia celowe było ujęcie informacji o nim w formę notatki (rozbudowanej wzmianki) ${ }^{14}$, która niejako wymusza selekcję

typologii zawężające jego zakres, a odwołujące się do parametrów komunikacyjnych (kto, do kogo, kiedy, w jakiej sytuacji, jakim kanałem, po co i o czym mówi) - a zatem można mówić o dyskursie (prasowym) wokół „sprawy Pyjasa”. Ujęcie takie profiluje kierunek analizy: od zdarzenia komunikacyjnego do jego wytworu - tekstu (I. Kamińska-Szmaj, Komunikacja politycz$n a$-język, styl, dyskurs, [w:] Style współczesnej polszczyzny. Przewodnik po stylistyce polskiej, red. E. Malinowska, J. Nocoń, U. Żydek-Bednarczuk, Universitas, Kraków 2013, s. 410).

9 „Dziennik Polski” 1977, nr 105, 11 V, s. 6; „Gazeta Południowa” 1977, nr 105, 11 V, s. 8 (OM, s. 648). Zasadą przyjętą w niniejszym artykule jest podawanie źródła cytowanych przykładów w przypisie po każdym śródtytule; wyjątkowo - źródło w przypisie po cytacie.

${ }^{10}$ Prokuratura uznała za przyczynę tragedii fakt, że student znajdował się w stanie ,poważnego stanu nietrzeźwości” i potknął się o nierówności posadzki. Zdaniem A. Paczkowskiego (Stanisław Pyjas - nieszczęśliwy wypadek...): „To mógł być wypadek, ale przy pracy esbeków, którzy być może chcieli go postraszyć. Ale być może chcieli go zabić...”.

${ }^{11}$ Oświadczenie Komitetu Obrony Robotników w sprawie śmierci Stanisława Pyjasa (OM, s. 19).

${ }^{12}$ Oświadczenie Ruchu Obrony Praw Człowieka i Obywatela w sprawie śmierci Stanisława Pyjasa (OM, s. 19-20).

${ }^{13}$ Dodatkowo istniała obawa, że „sprawa” dotrze do opinii międzynarodowej, ponieważ odbywało się w tym czasie międzynarodowe spotkanie architektów, które sprowadziło do Krakowa zagranicznych komentatorów.

${ }^{14}$ M. Wojtak, Analiza gatunków prasowych. Podręcznik dla studentów dziennikarstwa i kierunków pokrewnych, Wydawnictwo UMCS, Lublin 2008, s. 41. 
faktów, ogranicza do odpowiedzi na pytania: „kto, co, gdzie, kiedy”, czasem też: „dlaczego”. Pozory informacyjności i obiektywizmu budowały w planie leksykalnym rzeczowniki konkretne, nazwy własne, brak przymiotników i słownictwa nacechowanego; dodatkowo wrażenie faktograficzne potęgować miały przywoływane źródła:

Uzyskaliśmy informację, że w dniu 7. bm., w godzinach nocnych, przy ulicy Szewskiej 7 zdarzył się wypadek śmiertelny, któremu uległ Stanisław P. - student UJ. Według informacji KW MO w Krakowie, przyczyną wypadku w oparciu o oględziny miejsca zdarzenia oraz sekcji zwłok, dokonanej przez Zakład Medycyny Sądowej, śmierć nastąpiła w wyniku upadku ze schodów ww. posesji. Stwierdzono także u denata 2,6 promila alkoholu we krwi. Dochodzenie prowadzi prokuratura [podkreśl. D.S].

Manipulacja polegająca na przemilczaniu niewygodnych faktów ${ }^{15}$ oraz nagłaśnianiu, wyolbrzymianiu tych, które uzasadniają forsowaną tezę o przyczynie śmierci (obecność alkoholu we krwi zmarłego) ${ }^{16}$ stworzyła warunki wprowadzenia quasi-faktu poza asercją i oficjalnej peryfrazy: ,śmiertelny wypadek”, będącej przeciwwagą dla „morderstwa”, „zbrodni”. Tak ujęta nazwa kryzysowego zdarzenia funkcjonowała jako obowiązująca w kolejnych tekstach prasowych (ewentualnie z odmiankami, np. „nieszczęśliwy wypadek”), stając się leksykalnym kluczem propagandowej tezy o wypadku.

\section{Wokól „sprawy Pyjasa” - organizacja dyskursu}

Przebieg Juwenaliów pokazał jednak, że próba racjonalnego ramowania (framingu $)^{17}$ języka, jaki przyjęto na początku kryzysu w pierwszych wzmiankach, nie była ani wystarczająca, ani skuteczna. Sfunkcjonalizowane informacje

\footnotetext{
${ }^{15}$ Niektóre niewygodne fakty były znane nawet w oficjalnym obiegu, m.in. te o związku z KOR; Pyjas o anonimach od służby bezpieczeństwa i powodach, dla których były one fabrykowane, informował bowiem zarówno prokuraturę, jak i prasę. Powszechna była także wiedza o tym, że świadków ostatnich godzin życia studenta nie przesłuchała milicja, przyjmując od początku „swoją” wersję zdarzenia.

${ }^{16}$ M. Iłowiecki, Krzywe zwierciadło. O manipulacji w mediach, Wydawnictwo Archidiecezji Lubelskiej „Gaudium”, Lublin 2003, s. 75.

${ }^{17}$ Ramowanie, jako działanie manipulacyjne, ułatwia kształtowanie przekazu bezalternatywnego, arbitralnego (J. Bralczyk, O języku polskiej propagandy politycznej lat siedemdziesiątych, Wydawnictwo Trio, Warszawa 2007, s. 30-31).
} 
w jakiejś mierze ukształtowały odbiór zdarzenia początkowego ${ }^{18}$, ale nie zapobiegły rozwojowi kryzysu, którego tekstową realizacją stał się dyskurs prasowy wokół „sprawa Pyjasa”. Poznawczym i retorycznym zapleczem były m.in. teksty wytworzone przez aparat partyjny, funkcjonujące jako teksty-matryce w omawianym kryzysie ${ }^{19}$, np.:

Nowa prowokacja sil antysocjalistycznych. Wrogowie socjalizmu występujący pod fałszywymi, demagogicznymi szyldami podjęli nowe działania. Podstawę tych działań stanowi prowokacja, kłamstwo, dezinformacja. Odpowiadamy spokojem, odsłanianiem prawdy, szeroką informacją [...]. Nikt z zainteresowanych nie może twierdzić, że nie zna prawdziwego oblicza organizatorów prowokacji ${ }^{20}$ [podkreśl. D.S].

Matryce kształtowały zbiór oficjalnych motywów interpretacyjnych, wzorcowej leksyki, co dawało podstawy spójnemu przekazowi powielanemu w następnych publikacjach i wyjaśniającemu ,prawdziwe oblicze prowokacji”. Dyskurs prasowy - ,szeroka informacja” - był konieczny nie tylko po to, by neutralizować nastroje społeczne: właściwy obraz „brutalnej prowokacji ideologicznej" miał także wśród członków partii umacniać pryncypialną ideowość i zaufanie do władzy ludowej. Kolejnym etapom kryzysu towarzyszą teksty prasowe, w których silnie zaznacza się emocjonalny, konotacyjny profil (rama) komunikowania - już na poziomie tytułów ${ }^{21}$; pozory informowania wypiera kreowanie obrazu rzeczywistości i propagandowa rytualizacja jego składników.

18 Tajny współpracownik służb w relacji z 18 maja na temat nastrojów podczas Juwenaliów pisze: „Ostatnie artykuły w prasie spowodowały dalsze rozluźnienie atmosfery wśród studentów. Choć słyszy się głosy, że artykuły powyższe ukazały się za późno" (Informacja operacyjna [dokument operacyjny, obieg stużbowy], opracowana na podstawie doniesienia tajnego wspótpracownika pseud. „Agawa” dotyczacego Mszy św. odprawionej w kościele OO. Dominikanów w intencji zamordowanego Stanisława Pyjasa, 1977, 18 V, OM, s. 668).

${ }^{19}$ Zrytualizowane teksty-matryce (często w tej funkcji rozpowszechniania się przemówienia przywódców partyjnych) są typowe dla przekazu propagandowego: powtarzając motywy, hasła, słowa kluczowe, połączenia wyrazowe ustanawiają życzeniowy, umowny świat, utrwalają jednoznaczne wartościowanie, nie pozostawiają miejsca na interpretacje.

${ }^{20}$ Propagandowa broszura przygotowana po śmierci Pyjasa przez Wydział Pracy Ideowo-Wychowawczej KC PZPR (do użytku wewnątrzpartyjnego) w maju 1977 roku: Nowa prowokacja sit antysocjalistycznych (Materiat pomocniczy na zebrania POP, zajęcia szkoleniowe i lekarskie) (OM 704-708).

${ }^{21}$ Ulokowanie sygnałów ramowania w pozycji wyróżnionej strukturalnie jest szczególnie istotne, biorąc pod uwagę komunikacyjną funkcję tytułu w tekście medialnym. 


\section{6 maja: „Zakończyly się Juwenalia”22}

Poważnym sprawdzianem dla propagandy prasowej stały się wydarzenia w trakcie Juwenaliów, rozwijające kryzys: marsze z udziałem studentów i mieszkańców miasta, przebiegające pod hasłami sprzeciwu wobec dotychczasowych działań milicji, prokuratury, aparatu bezpieczeństwa, aresztowania studentów z innych miast oraz członków KOR, którzy chcieli w tych dniach uczestniczyć W uroczystościach żałobnych ${ }^{23}$. Artykuł napisany tuż po zakończonych Juwenaliach poddawał ideologicznej interpretacji kluczowe wydarzenia, jednocześnie utrwalał oficjalny przekaz o naturalnych przyczynach śmierci studenta.

Eksplikacja wydarzeń nawiązuje do sielanki²4 (młodzież uczy się, bawi, uznaje mądrość swoich przywódców), którą kształtuje głównie stylizacja leksykalna (nacechowane stylistycznie, archaizowane słownictwo, np. młodzieńczy, wesołość, uciecha), a wspomagają zjawiska składniowe (inwersja):

Tradycyjnie już przez trzy dni mieli krakowscy studenci swoje święto. W tym czasie tak władze uczelni, jak i miejscy rajcowie zezwalają żakom na ogólną wesołość, juwenaliowe igrce. Brać żakowska zapraszała krakowian do wspólnej zabawy. Oderwawszy się od swych codziennych zajęć, od nauki, ćwiczeń, wykładów, zaprezentowała swą mlodzieńczą wesołość. Nie sposób odnotować wszystkich uciesznych pomyslów żaków [...]. Święto krakowskiej braci - juwenalia mają już uświęcony swą wieloletnią tradycją jakże specyficzny nastrój wiosennej radości [podkreśl. D.S].

Sielance towarzyszy mit perswazyjny przyznający młodości prawo do błę$\mathrm{du}^{25}$, który będzie eksploatowany w każdym artykule, stając się podstawą strategii obniżającej rangę wydarzeń z udziałem studentów - jako sprowokowanych, nieświadomych ${ }^{26}$; to wróg, korzystając $\mathrm{z}$ młodzieńczej naiwności, próbuje zbu-

22 Niepodpisany artykuł z komentarzem redakcyjnym, Zakończyly się Juwenalia, „Dziennik Polski” 1977, nr 109, 16 V, s. 1-2 (OM, s. 652-654).

${ }^{23}$ Między 14 a 19 maja aresztowano wielu (ponad 50 osób) współpracowników KOR (m.in. Jacka Kuronia, Adama Michnika, Antoniego Macierewicza, Seweryna Blumsztajna). Przedstawiono im zarzuty ,kontaktowania się z obcą organizacją w celu działania na szkodę PRL oraz rozpowszechniania fałszywych informacji mogących zaszkodzić PRL”, http://www.kor.org.pl/index. php?page $=$ kalendarium\&sel=1977 [dostęp: 16.04.2016].

${ }^{24}$ Kanoniczną wersją jest sielanka stalinowska, pokazująca czasy Stalina jako okres spełnienia wartości i cech ustroju (M. Głowiński, Mowa w stanie oblężenia. 1982-1985, OPEN, Warszawa 1996, s. 10-11).

${ }^{25}$ Tradycję pokazywania młodości jako okresu grzechu wytworzyła propaganda gomułkowska (M. Głowiński, Mowa w stanie oblężenia, s. 30-31).

26 Ton paternalistyczny (w wersji: ,przemawianie do rozsądku”) był obecny w kryzysowej propagandzie z początku stanu wojennego (tamże, s. 8). 
rzyć społeczną i polityczną idyllę. Paternalistyczny ton relacji o sukcesie, jakim było przeprowadzenie Juwenaliów zgodnie z planem, nadawały kontrastowe zestawieniami leksyki o silnych konotacjach (np. igrce studenckiej braci vs. ukartowana gra, politykierstwo), czasowniki z wpisanym wartościowaniem czynności (wplątać, wciagnać) czy osłabianiem ich skutku (starano się), propagandowe szablony (,,podejmowane szerokim frontem próby”, ,program był realizowany w pełni i spokoju”):

Ale znaleźli się ludzie, którzy założyli sobie, że tegoroczne igrce studenckiej braci wykorzystają jako okazję do wciągnięcia młodych ludzi w politykierstwo. Znaleziono powód, nawet tak dramatyczny i bolesny, jak śmierć SP, studenta V roku filologii polskiej UJ [...] Wszelkimi sposobami starano się wzniecić w młodych sercach i umysłach zarzewie niepokoju, wplątać w tę z góry ukartowaną i organizacyjnie przemyślaną grę [...]. Na pochwałę krakowskiej młodzieży trzeba zapisać to, że mimo podejmowanych szerokim frontem prób, program juwenaliowych Dni był realizowany w pelni i spokoju [podkreśl. D.S].

Pozory racjonalnego oglądu towarzyszą jeszcze refleksji autora dotyczącej przyczyny śmierci: ,[...] był to po prostu nieszczęśliwy wypadek związany z nadmiarem alkoholu'. Co więcej, ten wypadek usprawiedliwia się protekcjonalnie, wskazując znów na błąd młodości, ale też splatając te wydarzenia z wrogą motywacją ideologiczną:

Nie idzie o to by potępiać styl bycia nieżyjącego czlowieka. [...] Jednakże wobec faktu, że przy pomocy m.in. zagranicznych ośrodków antypolskich, przez rozwieszanie kłamliwych ulotek w niektórych domach akademickich itp. chce się narzucić opinii haniebną konfrontację nad zwłokami czlowieka, trzeba tu prawdę powtórzyć: nocna eskapada Stanisława P. z 6 na 7 maja po wypiciu dużej ilości alkoholu tak się właśnie zakończyła. I tylko nikt nie był stanie przewidzieć, że jej smutny kres stanie się w sam raz dobrą okazją do akcji polityczno-propagandowej przeciwko naszemu państwu [podkreśl. D.S].

W całym tekście dominowała jednak strategia emocjonalnego ramowania przekazu perswazyjnego, a wraz z nią jednowartościowe środki językowe: zróżnicowane etykiety ${ }^{27}$, propagandowe przymiotniki (kłamliwe, haniebna), zaimki

${ }^{27}$ Etykietowanie (labelling) to językowy sposób deprecjacji przeciwnika, jego zachowań (negatywne wyróżnienie i uproszczona, ale wyrazista ocena/wartościowanie), wykorzystywany w działaniach retorycznych i erystycznych (R. Zimny, P. Nowak, Słownik polszczyzny politycznej po roku 1989, Wydawnictwo Naukowe PWN, Warszawa 2009, s. 314). W dyskursie politycznym źródłem oceny są m.in. określone konotacje i kontekst polityczno-ideologiczny, uaktywniający presupozycyjnie wartościowanie (D. Suska, Frazeologia w dyskursie politycznym po 1989 roku 
inkluzywne (wyznaczające wspólnotę, także z udziałem tych, którzy zbłądzili). Omawiany artykuł rysował jeszcze dość ogólny obraz wroga ${ }^{28}$ i motywacji jego działań, zgodny z linią interpretacji kryzysu wyznaczoną przez aktualne teksty matrycowe: (środowiska przeciwników socjalizmu, gracze polityczni, prowokacja polityczna, akcja polityczno-propagandowej przeciwko naszemu państwu). Odwoływał się też do typowej, „esbeckiej” insynuacji (powielanej w kolejnych publikacjach) o szczególnie niskich, finansowych pobudkach działania wroga i zależności finansowej od zagranicznych ośrodków. Odejście od dyskursu racjonalnego potwierdzają coraz liczniejsze elementy rytualne:

W ostatnich miesiącach - wobec wymowy faktów, niedwuznacznie świadczących, iż polityka wewnętrzna Rzeczpospolitej Ludowej realizuje się na konstytucyjnych zasadach wolności i powinności obywatelskich i że stanowi ona rzeczywistą realizację ducha KBWE - zainteresowanie zachodnich ośrodków antykomunistycznych i zimnowojennych dla działan środowiska przeciwników socjalizmu wyraźnie zmalało. W takiej sytuacji nagły zgon studenta stał się dogodną okazją dla niegodnej akcji propagandowej $[. .$.$] ludzi usiłujących stworzyć ośrodki podju-$ dzania i siania niepokoju [podkreśl. D.S].

\section{8 maja: „Prawda o jednej prowokacji” ${ }^{29}$}

Włączenie figury wroga $\mathrm{w}$ doraźną propagandę kryzysu wynikało m.in. z konieczności legitymizacji aresztowań członków KOR w Krakowie lub w drodze na uroczystości żałobne. Artykuł już na poziomie tytułu narzucał (poprzez presupozycję ${ }^{30}$ ) punkt widzenia, a zestawienie słów o skrajnych konotacjach (,prawda” - „prowokacja”) dodatkowo wzmacniało wydźwięk perswazyjny. Kształtowanie negatywnego odbioru KOR opierało się na sygnalizowaniu uzurpacyjnego charakteru samej nazwy („tzw.”, w innych artykułach w tej funkcji także cudzysłów) ${ }^{31}$ :

(wybrane zagadnienia), [w:] Paremie narodów słowiańskich VI, red. L. Mrověcová, Ostrava 2012, s. 248-249).

${ }^{28}$ Kluczowa dla propagandy figura wroga przywoływana była przede wszystkim w okresach kryzysu, gdy istniała potrzeba szczególnego wyeksponowania jednoznacznej i bezalternatywnej kwalifikacji aksjologicznej.

29 [Bez autora], Prawda o jednej prowokacji, „Życie Warszawy” 1977, nr 116, 18 V, przedruk w prasie krakowskiej: „Gazeta Południowa” 1977, nr 11, 18 V, „Dziennik Polski” 1977, nr 112, 19 V (OM, s. 669-672).

${ }^{30}$ Presupozycyjność polega na wprowadzeniu sądów, którym przypisuje się oczywistą prawdziwość i które uniemożliwiają reakcję w postaci prostej negacji (J. Bralczyk, dz. cyt., s. 98-99).

${ }^{31}$ Tamże, s. 94. 
W ostatnich dniach, jak informowaliśmy już przeciwnicy władzy ludowej, zgrupowani w tzw. Komitecie Obrony Robotników, usiłowali wykorzystać tragiczną śmierć studenta Uniwersytetu Jagiellońskiego do zmącenia atmosfery politycznej w środowisku akademickim i zmobilizowania opinii międzynarodowej przeciwko Polsce [podkreśl. D.S].

Wróg został także spersonalizowany, a pozorne niedomówienie stwarzało sugestię porozumiewania z obiorcą, który podobnie jak nadawca potrafi wskazać ,innych”:

Jacek Kuroń, Adam Michnik, Antoni Macierewicz, Jan Józef Lipski i inni, znani z wcześniejszych wystąpień przeciwko socjalizmowi, rozpoczęli kolportować wyssaną z palca wersję śmierci, że Stanisław Pyjas został z premedytacją przez organa porządku publicznego „zamordowany” dla zastraszenia innych [podkreśl. D.S].

Drobiazgowa, wartościująca analiza działań „emisariuszy KOR” propagandowo uzasadniała represyjne działania władzy i utrwalała opinię, iż ich powodem stała się ,szkodliwa działalność przeciwko swemu państwu w porozumieniu z obcą, zagraniczną organizacją”. Jednocześnie pomniejszano skutki oddziaływania wroga (mała liczebność, nieskuteczność), pisząc o „grupie osób”, która „starała się" przekształcić uroczystości pogrzebowe w ,imprezę o wydźwięku politycznym”, „nie zdołała osiągnąć celu na miarę swoich awanturniczo-politykierskich ambicji”, studenci „nie dali się nabrać na przemyślnie przygotowaną prowokację”. Po raz kolejny aktualizowany był motyw grzesznej młodości, w pełni usprawiedliwiający nielicznych studentów, którzy wprawdzie nie wykazali się w danej chwili ,mądrością polityczną”, pozwolili ,się wciągnąć do tej akcji”, ale za to ,wiedzą dziś lepiej, że zostali oszukani”. Marginalizowanie świadomego uczestnictwa studentów w „sprawie Pyjasa” i przeniesienie odpowiedzialności na ,wytrawnych graczy” (,niektórzy z nich z podobnym cynizmem próbowali już wykorzystać uczucia i dobrą wiarę młodzieży, np. w marcu 1968 roku”) miało też ogólniejszy cel: budowanie środowiskowych antagonizmów i dążenie do rozbicia opozycji demokratycznej.

\section{0 maja: „O dojrzałości i rozwadze”32}

15 maja pojawiła się inicjatywa powołania Studenckiego Komitetu Solidarności, po tym jak część studentów uznała że: „Organizując manifestacyjne Juvenalia w dniach żałoby po tragicznej śmierci SP studenta UJ SZSP [Socjalistyczny

\footnotetext{
${ }^{32}$ R. Łukasiewicz, O dojrzałości i rozwadze, „Sztandar Młodych” 1977, nr 119, 20 V, s. 2 (OM,
} s. 672-674). 
Związek Studentów Polskich] zdemaskował się jako usłużne ramię Służby Bezpieczeństwa i PZPR" 33 . Propagandowa neutralizacja tego wydarzenia wymagała szczególnie wyrazistego dookreślenia obu stron konfliktu, dlatego też punktem wyjścia stało się streszczenie „sprawy Pyjasa”, powtarzające oficjalne motywy, bazujące z jednej strony na leksyce deprecjonującej działania wroga (macenie, obcość, prowokacja), z drugiej zaś - na sugestii wspólnotowego porozumienia, podkreślonej elementami fatycznymi (,powiedzmy to wprost”, „przypomnijmy”):

Opinii publicznej w Polsce znana jest już sprawa kolejnej próby mącenia atmosfery politycznej w środowisku akademickim, jaką podjęli ludzie z tzw. komitetu obrony robotników, w trakcie trwania w Krakowie tradycyjnych Juwenaliów. [...] przebieg krakowskich Juwenaliów stał się okazją do politycznej konfrontacji środowiska studenckiego z, powiedzmy to wprost, przybyłymi spoza Krakowa znanymi mącicielami porządku publicznego - ludźmi od lat wysługującymi się zagranicznym ośrodkom dywersji antysocjalistycznej, ludźmi, którzy sprawy naszego kraju chcieliby rozstrzygać poza granicami Polski. W konfrontacji tej studenci nie dali się zwieść prowokatorom. Tym ostatnim chodziło - przypomnijmy - o zbojkotowanie Juwenaliów, o przeksztalcenie ich $\mathbf{w}$ antysocjalistyczną, antypolską demonstrację, wykorzystując w tym celu dotychczas do końca nie wyjaśnione okoliczności śmierci jednego ze studentów UJ [podkreśl. D.S].

Na tym tle budowana była jednoznacznie pozytywna ocena związku (eksplicytnie już w tytule oraz w tekście wartościującymi rzeczownikami, przymiotnikami, propagandowymi szablonami: „dali dowody ideowej i politycznej dojrzałości”) oraz umniejszanie roli środowiskowych oponentów, podkreślanie fiaska działań zewnętrznych prowokatorów:

Kilkudziesięcioosobowa grupa, w większości spoza Krakowa, różnymi sposobami próbowała zakłócić wspólną zabawę [...]. Jeżeli próby te nie powiodły się, a przecież rzeczywiście zakończyły się fiaskiem, to jest zasługą rozwagi, rozsądku i postawy zajętej przez większość akademickiego środowiska Krakowa i rozważnego działania krakowskiego aktywu SZSP [...]. Organizatorzy prowokacji liczyli na to, że w okresie Juwenaliów [...] łatwiej będzie narobić zamieszania. I przeliczyli się. Krakowscy studenci okazali się dobrymi gospodarzami miasta, wykazali sprawność organizacyjną i w niemalym stopniu dali dowody ideowej i politycznej dojrzałości [podkreśl. D.S].

${ }^{33}$ Ulotka wzywająca do bojkotu Juwenaliów [przed 13 maja], Obieg niezależny, druk ulotny (OM, s. 24). 
Artykuł przemilczał powstanie nowego związku studenckiego, skupiał się w całości na wykluczeniu jakichkolwiek odstępstw od obecnego porządku ideologicznego i ukazaniu mitu (sielanki) jedności środowiska studenckiego, którą kreowały deklaratywnie słowa klucze (wspólnota, praca, więź) wpisane w propagandowe schematy (na rzecz, na polu):

Polityczni prowokatorzy próbowali dyskredytować organizację studentów - SZSP. Związek jednak ma mocne poparcie w środowisku akademickim. Głęboka więź młodzieży studenckiej ze swoją organizacją ukształtowana została w codziennej wspólnej pracy na rzecz środowiska studenckiego, w działalności na rzecz poprawy socjalno-bytowych warunków życia studentów, w walce o nowoczesną szkołę wyższą [...]. Umacnia się ta więź we wspólnie programowanej i wspólnie wykonywanej pracy na rzecz swoich uczelni, miast, kraju.

Wpisana w przekaz kategoria słuszności wykluczała weryfikację formułowanych sądów, zrównując rzeczywistość postulowaną z realną. Generalnie, wprowadzenie kanonicznych formuł propagandowych (fragmenty tekstów matrycowych, sądy poza asercją i w ogólności retoryka wiecowa) pozwalało nie tylko budować propagandowe wartościowanie aktualnych wydarzeń, ale także utrwalało bazę ideologiczną zachwianą nasilającymi się działaniami opozycji (nie tylko w środowisku krakowskim):

Środowisko polskich studentów w swej zdecydowanej większości nie było i nie będzie obiektem politycznych machinacji, brudnych gier politycznych. Młodzież studencka jest świadomie i emocjonalnie związana $z$ programem budownictwa socjalistycznego w Polsce, wytyczonym przez partię polskiej klasy robotniczej. Ten program bowiem najpełniej odpowiada jej dążeniom i aspiracjom [podkreśl. D.S].

\section{1-22 maja: „Wbrew interesom narodu. Manowce prowokacji” 34}

Propagandowo ukształtowana wersja śmierci Pyjasa pojawiała się obowiązkowo w strukturze kolejnych artykułów prasowych; tej „,kryzysowej” matrycy towarzyszyło zawsze (mniej lub bardziej rozbudowane) dookreślenie i wartościowanie wszystkich uczestników:

34 [Bez autora], Wbrew interesom narodu. Manowce prowokacji, „Trybuna Ludu” 1977, nr 119, 21-22 V, s. 4 (OM, s. 674-676). 
Jak doniosła prasa krakowska [...] w nocy z 6 na 7 maja br. w Krakowie poniósł śmierć w nie wyjaśnionych jeszcze do końca okolicznościach student polonistyki UJ, Stanisław Pyjas. To tragiczne wydarzenie próbowała wykorzystać grupa osób, znanych od dawna ze swoich wrogich Polsce Ludowej przekonań oraz mącicielskiej działalności politycznej. [...] Zamierzenia owych politycznych mącicieli nie powiodły się. Młodzież studencka nie posłuchała prowokacyjnych propozycji i nie dała się nakłonić do szerszego uczestnictwa w akcji, której rzeczywistym celem były nie żałobne egzekwie, ale opozycyjna i częściowo polityczna demonstracja. Prowokatorzy zajść krakowskich liczyli na polityczną niedojrzałość młodzieży [...] i sądzili, że łatwo będzie ją użyć do wrogiej Polsce dzialalności [podkreśl. D.S].

W miarę rozwoju dyskursu, w manipulowaniu obrazem rzeczywistości matrycę „kryzysową” coraz częściej uzupełniały matryce „ogólnopropagandowe”: osłabiając aktywny odbiór treści, ułatwiały bowiem włączenie w nie pożądanej wizji i oceny bieżących faktów, a ponadto wzmacniały strategię identyfikacji odbiorcy z wyrażanymi deklaracjami. Przewodnim motywem był ,interesu narodu”, w imię którego „społeczeństwo polskie” solidarnie (sugestia ideologicznej jedności różnych grup społecznych) potępiało działanie „fałszywych obrońców robotników" (ezopowa peryfraza KOR):

Społeczeństwo polskie zajęte jest pracą, trudzi się nad rozwiązaniem spraw decydujących o dalszym rozwoju kraju, o dalszej poprawie warunków życia. VII Zjazd nakreślił zadania, z których wypływa troska partii i państwa o rozwój socjalistycznego budownictwa i utrwalanie socjalistycznego budownictwa, utrwalanie socjalistycznych stosunków społecznych, o żywotne interesy narodu. To nie naciski fałszywych obrońców robotników, ale założenia programowe i codzienna praktyka partii tworzą warunki gwarantujące rozwój demokracji [...]. Klasa robotnicza odrzuca próby szermowania jej imieniem przez grupę awanturników politycznych [...]. Odrzuca je również młodzież [podkreśl. D.S].

Eksplikacji bieżących wydarzeń (peryfraza ,trudności i kłopoty”) podporządkowano także propagandowy motyw kryzysu jako naturalnego, przejściowego etapu na drodze postępu społecznego; pojawiał się zwykle obudowany deklaracjami ideowymi wygłaszanymi z perspektywy wspólnotowej:

Żaden postęp, żaden rozwój nie może być wolny od trudności i kłopotów. Nie brak ich i na naszej drodze. Pokonujemy je wspólnym ogólnonarodowym wysiłkiem [...], coraz szerzej rozwijamy zasady demokracji socjalistycznej [...]. Coraz pełniej urzeczywistniamy ideę ludowładztwa. Olbrzymia większość naszego społeczeństwa wnosi do tego procesu swoją cenną aktywność - i czynnie, odpowiedzialnie w nim uczestniczy. Uczestniczy w nim również młodzież studencka, przygotowująca się 
do podjęcia niezwykle ważnej roli w budowie społecznej i gospodarczej przyszłości naszego kraju. [...] Prowokatorzy polityczni z pewnością nie znajdą w jej szeregach sympatyków - tak, jak nie znaleźli ich wcześniej wśród klasy robotniczej [podkreśl. D.S].

\section{0 maja: „Komu szkodzą?”35}

$\mathrm{Na}$ krytyce Kościoła, reagującego nie tylko na aktualne „wydarzenia krakowskie"36, ale i współuczestniczącego na co dzień w budowaniu postaw niezależnych, skupił się ostatni artykuł zamykający serię krakowskich tekstów prasowych wokół sprawy Pyjasa. Najsilniej spośród wcześniejszych publikacji zaznaczyła się w nim retoryka pamfletowa - deprecjacja, ośmieszanie KOR, skutków „szkodzenia” w tonie ironizującym, silnie ekspresywnym, potocznym (m.in. poprzez nacechowaną leksykę, konkretne obrazowanie). W całym tekście wróg funkcjonował najczęściej w zamierzonym niedopowiedzeniu - jako grupa, która realizuje cel w różnych okresach:

Wiemy aż nadto doskonale, że autorzy nieudanych scenariuszy, to właśnie wytrawni gracze, rutynowi i dobrze oblatani w swoim fachu. Niektórzy swoje kwalifikacje zdobywali jeszcze przed wojną, a po wojnie manipulując na różnych czerwcowych, październikowych i marcowych instrumentach, próbowali odwracać polski porządek rzeczy i zawracać w tamte, „lepsze czasy” [podkreśl. D.S].

Aktualne działania wroga (,wytrawnych graczy” piszących „scenariusze”, którym „majaczy się władza”) pomniejszała powtarzana leksyka z kręgu niepowodzenia (mrzonki, klops, kolejna klapa i in.):

Nie wypalil Kraków, nie udało się przekształcić dorocznego święta radości krakowskich studentów w „,czarne Juwenalia”. Przywieziony do Krakowa scenariusz prowokacji spalil na panewce.

Nie sprowokowali środowiska krakowskiego, nie udało się sprowokować upatrzonych środowisk stołecznych, więc zamiast tego zmontowali grupę osób [podkreśl. D.S].

${ }^{35}$ J. Kochański, Komu szkodzą?, artykuł z agencji „Interpress”, druk w: „Echo Krakowa” 1977, nr 121, 30 V, s. 3 (OM, s. 693-695).

3624 maja w kościele św. Marcina w Warszawie rozpoczęła się głodówka protestacyjna zorganizowana przez środowisko KOR, podczas której domagano się m.in. uwolnienia protestujących w związku ze sprawą Stanisława Pyjasa. 
Ciąg niepowodzeń, kompromitacji z początkowej fazy kryzysu był wstępem do propagandowej neutralizacji aktualnego wydarzenia - głodówki w kościele warszawskim przedstawianej osobliwym udosłownieniem frazeologizmu: „wytrawni gracze” sięgnęli po metodę ,gry na ludzkiej wrażliwości” i „chcą - mimo dwóch swoich klęsk - trafić przez żołądek do serc". Potoczna w tonie narracja nakreślała też szerszą perspektywę interpretacyjną tego zdarzenia, zapowiadaną pytaniami sugerującymi dialog (,O co im w istocie chodzi? O protest $\mathrm{w}$ jakiej sprawie i przeciwko komu?”, „Jakimi metodami się posługują?”), które miały potęgować wrażenie porozumienia (i zrozumienia) z odbiorcą. W takiej sytuacji łatwiej było narzucić ekspresywne uzasadnienie aresztowania „burzycieli porządku” aktywnych w czasie ,sprawy Pyjasa” oraz potępić zagranicznych mocodawców:

Z trzydziestoletniego doświadczenia wiemy, że po tamtej stronie są ugrupowania, środowiska i koterie, którzy tylko czekają na okazję. Tradycyjnie są to: dobrze wypróbowana w takich aliansach Wolna Europa, środowiska niedobitków spod znaku zachodnioniemieckiego rewanżyzmu. [...] A dalej: bankruci grupujący się wokól tak zwanego Instytutu Literackiego w Paryżu i jego organu „Kultura”.

Sięgnęli do przypadkowego nieszczęśliwego wypadku krakowskiego studenta. Zanim władze porządku publicznego i organa powołane do wyjaśnienia sprawy Pyjasa, zdążyły cokolwiek powiedzieć, już puścili w świat grubymi nićmi szyte kłamstwo. Nieszczęśliwy wypadek rozreklamowali za pomocą zagranicznych dziennikarzy akredytowanych w Polsce, jak - nie przymierzając - gumę do żucia czy artykuł wyskokowy [podkreśl. D.S].

Artykuł był próbą wygaszania dyskursu wokół „sprawy Pyjasa”, co oznaczało odejście od minimalnej choćby racjonalizacji aktualnych faktów na rzecz ich wpasowania w wykreowaną i utrwaloną we wcześniejszych tekstach siatkę wartości, schematów interpretacyjnych, także sprawdzonych środków. Stąd podsumowaniem wywodu stała się zrytualizowana pochwała mądrości Polaków - w retoryce wiecowej, z motywem m.in. sielanki (,,społeczny i polityczny spokój"), ekspresywnymi powtórzeniami, kalkami leksykalnymi i składniowymi, które współtworzą iluzję jedności celów partii i społeczeństwa ${ }^{37}$ :

Bo my - Polacy nauczyliśmy się odróżniać plewy od ziarna. My - Polacy, mamy przecież konkretne cele: socjalistyczną przyszłość, dostatek ludzi pracy, siłę kraju, jedność społeczeństwa. [...] Te zadania realizujemy z dużym powodzeniem, bo siłą

${ }^{37}$ Taki rodzaj strategii (iluzja jedności) wywodził się z gierkowskiej propagandy sukcesu (I. Kamińska-Szmaj, Komunikacja polityczna..., s. 419). 
napędową jest wielki nasz patriotyczny obowiązek, konsekwentne trzymanie się socjalistycznej szansy rozwoju. [...] Za dużo mamy spraw do rozwiązania, za dużo mamy przed sobą pracy dla siebie, żebyśmy się mogli godzić z różnego pokroju mącicielami. Zawsze, ale dziś szczególnie, potrzebny jest po prostu spokój. Właśnie ten społeczny i polityczny spokój. Właśnie ten społeczny i polityczny spokój do pracy, który również jest wielką zdobyczą lat powojennych.

\section{„Uwalniany" ${ }^{38}$ głos studentów}

Częścią ówczesnej kultury politycznej39 były teksty drugiego obiegu, w których odbijały się niejako działania propagandowe i które stanowiły rodzaj informacji zwrotnej. Zapowiadały wyjście z układu komunikowania jednokierunkowego i późniejsze „uwolnienie słów” poprzez komentowanie manipulacyjnie ukształtowanych etykiet, metafor i odnoszenie ich do rzeczywistości (i rzeczywistych znaczeń), przełamywały bowiem funkcję magiczną propagandowego przekazu, bez której tracił możliwość funkcjonowania poza asercją, tym samym poza krytyką.

Dla analizowanego dyskursu taką funkcję pełniło m.in. oświadczenie środowiska studenckiego ${ }^{40}$, które odsłaniało prasowe manipulacje faktami i ocenami. Sposób werbalizowania perspektywy uczestników zdarzeń poświadczał jednocześnie proces rewindykacji języka, docierania do znaczeń zmanipulowanych propagandowo:

My, akademicka młodzież Krakowa, protestujemy przeciwko publikowaniu na łamach prasy [...] kłamliwych i oszczerczych, a przede wszystkim wypaczonych informacji dotyczących wydarzeń $z$ dn. 15 maja br. Pragniemy wyjaśnić, że chcieliśmy uczcić pamięć naszego kolegi, tragicznie zmarłego Stanisława Pyjasa, a nazwanie załoby ,antysocjalistyczną awanturą" przynosi hańbę samym autorom prasowych publikacji. Wierzymy, że polskie społeczeństwo nie da się zwieść fałszywym i oszczerczym oświadczeniom prasy o, ,brutalnej prowokacji politycznej”, o ,propagandowej dywersji antypolskiej” [...] odmawia się nam prawa do

${ }^{38}$ Odwołuję się tutaj do metaforycznego ujęcia przemian w języku polityki, czyli „uwalniania słów": I. Kamińska-Szmaj, Słowa na wolności: język polityki po 1989 roku, Wydawnictwo EUROPA, Wrocław 2001.

${ }^{39}$ Pojęcie kultury politycznej precyzuje I. Kamińska-Szmaj, Co to jest kultura polityczna?, [w:] Język polityki a współczesna kultura polityczna, Język a kultura, t. 11, red. J. Anusiewicz, B. Siciński, Towarzystwo Przyjaciół Polonistyki Wrocławskiej, Wrocław 1994, s. 9-14.

${ }^{40}$ Oświadczenie studentów krakowskich w sprawie przebiegu wydarzeń z 15 maja, znane tylko z odpisu wykonanego przez SB w Krakowie. Obieg służbowy MSW, dokument operacyjny [odpis druku ulotnego], 19 maja 1997 [data na dokumencie] (OM, s. 41). 
przedstawiania społeczeństwu naszego stanowiska, brutalnie tłumi się wszelkie próby wypowiedzenia własnych poglądów i dlatego oficjalna prasa może ciskać gromy na nasze głowy, nazywając ,politykierami”, twierdząc, że działalność nasza kierowana jest przez ośrodki dywersyjne [podkreśl. D.S].

„Prawdziwe fakty” przedstawił także Studencki Komitet Solidarności w Krakowie ${ }^{41}$, podkreślając jednocześnie „świadome wykrzywianie rzeczywistości” w mediach po śmierci Stanisława Pyjasa. Komitet wskazywał m.in. na tworzony w oficjalnej prasie mit radosnego, studenckiego święta, na rzekome wyobcowanie grupy studentów zabiegających o uczczenie śmierci kolegi.

Doniesienia prasowe o ,groźbach i szantażach” powiększają jedynie nieufność wobec środków masowego przekazu. Nie wdając się w analizę zafałszowań, warto przytoczyć parę ewidentnych przykładów: całkowicie falszywa informacja prasowa o próbie zakłócenia przebiegu uroczystości pogrzebowych [...]. Społeczeństwo Krakowa masowo, lecz bez ekscesów, w ciszy i skupieniu oddało hołd tragicznie Zmarlemu studentowi. Nie było w tym roku hucznych Juwenaliów, o których informowala prasa [podkreśl. D.S].

\section{Wnioski}

Kryzys wokół „sprawy Pyjasa” miał szersze podłoże i wynikał ze zmiany niektórych aspektów dominującej w drugiej połowie lat 70. kultury politycznej. Przyczyniły się do tego protesty przeciwko systemowi (1976 rok), aktywność opozycyjna środowisk inteligenckich i studenckich, inicjatywy kontestujące (przede wszystkim w wymiarze moralnym) porządek polityczny Polski ,„ṕźnego Gierka”, liczne „świadectwa sprzeciwu” wobec totalitarnego porządku politycznego PRL: broszury, ulotki, odezwy, pisma założycielskie, deklaracje, czasopisma funkcjonujące w drugim obiegu. W konsekwencji zarysowała się niewielka zmiana komunikowania politycznego w ówczesnych mediach: wprawdzie nadal był to przekaz jednostronny, ściśle kontrolowany przez rządzących, ale z osłabieniem komunikacji poddańczej (dominującej) i pozorowaniem komunikacji uczestniczącej. Kryzys wywołany śmiercią Stanisława Pyjasa stał się sprawdzianem dla nowomowy - pozostając językiem władzy, musiała ona uwzględniać enklawy „słowa prawdziwego" w nieoficjalnej prasie, w odezwach, w nauczaniu Kościoła. Jednak o specyfice strategii zarządzania kryzysem w omawianym dyskur-

${ }^{41}$ Studencki Komitet Solidarności w Krakowie, Opis wydarzeń, 22 V, Obieg niezależny, druk ulotny (OM, s. 41-43). 
sie prasowym stanowi nie tyle nowatorstwo środków retorycznych, językowych, ile ich różnorodność, intensywność, kolażowość: elementów rytualnych (matryc ogólnopropagandowych i doraźnych, z rozmaitymi mitami), potocznych (odwołujących się do doświadczenia codziennego odbiorcy), wzniosłych stylizacji, kanonicznej leksyki propagandowej, elementów dowcipu, ironii. Kluczowa dla repertuaru propagandy jest figura wroga, tu rozmaicie wypełniana leksykalnie oraz czerpiąca z wcześniejszych opozycji aksjologicznych, etykiet, peryfraz. Do językowych wykładników komunikacji kryzysowej należy też zaliczyć etykiety, gdyż generalnie nie były one charakterystyczne dla języka polityki lat $70 .{ }^{42}$ Etykiety pomagały kreować rzeczywistość (peryfrazy śmierci studenta, zajść podczas Juwenaliów), sterować jej odbiorem i porządkować ją w potocznej świadomości (przede wszystkim przestrzeń wroga). Były wygodnym i bardzo skutecznym narzędziem manipulacji, zważywszy choćby na fakt, że ocena dominowała w nich nad odniesieniem do weryfikowalnych cech osób, zdarzeń, motywacji działania, a sam mechanizm deprecjacji wiązał się z eksponowaniem takich składników semantycznych, które wywoływały oceniające konotacje. Najczęściej pojawiały się w postaci peryfraz, reprezentatywnych dla języka ezopowego, bazującego na eufemizującym podświetleniu cech, które łączyły się z korzystną dla nadawcy wizją rzeczywistości. Na uwagę zasługuje także wysoki stopień szablonowości językowej oraz ideologiczno-tematycznej, co w sytuacji, gdy chodzi o sugestię wspólnoty celów nadawcy i odbiorcy ma charakter funkcjonalny: zapewnia jednolity przekaz, utrwala to, co z punktu widzenia nadawcy istotne, a więc spełnia propagandowy cel wyłączenia innych obrazów i ocen kryzysowych zdarzeń.

\section{Bibliografia}

Bralczyk J., O języku polskiej propagandy politycznej lat siedemdziesiatych, Wydawnictwo Trio, Warszawa 2007.

Głowiński M., Mowa w stanie oblężenia 1980-1985, OPEN, Warszawa 1996.

Głowiński M., Nowomowa po polsku, Wydawnictwo PEN, Warszawa 1991.

Iłowiecki M., Krzywe zwierciadło. O manipulacji w mediach, Wydawnictwo Archidiecezji Lubelskiej „Gaudium”, Lublin 2003.

Kamińska-Szmaj I., Co to jest kultura polityczna?, [w:] Język polityki a współczesna kultura polityczna, Język a kultura, t. 11, red. J. Anusiewicz, B. Siciński, Towarzystwo Przyjaciół Polonistyki Wrocławskiej, Wrocław 1994, s. 9-14.

Kamińska-Szmaj I., Komunikacja polityczna - język, styl, dyskurs, [w:] Style współczesnej polszczyzny. Przewodnik po stylistyce polskiej, red. E. Malinowska, J. Nocoń, U. Żydek-Bednarczuk, Universitas, Kraków 2013, s. 407-465.

Kamińska-Szmaj I., Stowa na wolności: język polityki po 1989 roku, Wydawnictwo EUROPA, Wrocław 2001.

${ }^{42} \mathrm{~W}$ przeciwieństwie do lat poprzednich niewiele jest nazw wyrastających z ówczesnego kontekstu polityczno-ideologicznego (J. Bralczyk, dz. cyt., s. 66). 
Opozycja małopolska w dokumentach 1976-1980, wybór i oprac. A. Roliński, Fundacja Centrum

Dokumentacji Czynu Niepodległościowego, Kraków 2003.

Puzynina J., Stowo - wartość - kultura, TN KUL, Lublin 1997.

Stanisław Pyjas - nieszczęśliwy wypadek czy morderstwo?, z komentarzem historyka, prof. A. Paczkowskiego; audycja z cyklu Dźwiękowy przewodnik po najnowszej historii Polski, PR, 15.04.1997, http://www.polskieradio.pl/39/156/Artykul/837672, Stanislaw-Pyjas-nieszczesliwy-wypadek-czy-morderstwo [dostęp: 16.04.2016].

Suska D., Frazeologia w dyskursie politycznym po 1989 roku (wybrane zagadnienia), [w:] Paremie narodów stowiańskich VI, red. L. Mrověcová, Ostrava 2012, s. 241-252.

Wojtak M., Analiza gatunków prasowych. Podręcznik dla studentów dziennikarstwa i kierunków pokrewnych, Wydawnictwo UMCS, Lublin 2008.

Zimny R., Nowak P., Stownik polszczyzny politycznej po roku 1989, Wydawnictwo Naukowe PWN, Warszawa 2009.

\section{Dorota Suska}

\section{The discourse around the death of Stanisław Pyjas (linguistic crisis management methods in the press Krakow)}

\section{(Summary)}

The article presents (from a linguistic perspective) the strategies of describing and evaluating the events of May 1977, which activated part of the students' environment (critical to the authority) and the opposition during Juwenalia (annual Polish students' holiday). The direct cause was the death of a Jagiellonian University Polish Philology student, Stanisław Pyjas, who had previously been within the range of interest of the security services. The analysis of the then official-circulation press and (complementarily) a KC PZPR (Central Committee of the Polish United Workers' Party) propaganda booklet (produced by the Department of Ideological-Educational Activity for internal use) has enabled the author to indicate the linguistic (rhetorical) means that were used for dealing with the crisis, including the ways of demoting the opponent ("they"), creating a positive image of the authority and its supporters ("we"), euphemizing events, and profiling assessments.

Keywords: language of propaganda; political lexis; rhetoric of political crisis. 